Avaing Tera
Ling Tera, $6(1), 2019,91-99$

\title{
Pengembangan tes membaca Bahasa Indonesia berbasis web bagi mahasiswa Thailand di Universitas Negeri Yogyakarta
}

\author{
Aleeyah Masae \\ Department of Melayu, University Yala Rajabhat. \\ 133 ถนน เทศบาล 3 Tambon Sateng, Mueang Yala District, Yala 95000, Thailand \\ * Coresponding Author. E-mail: aleeyah18@yahoo.com \\ Received: 13 March 2018; Revision: 15 April 2019; Accepted: 19 June 2019
}

\begin{abstract}
Abstrak
Penelitian ini bertujuan untuk menghasilkan instrumen tes hasil belajar pemahaman membaca Bahasa Indonesia berbasis web yang dapat digunakan oleh mahasiswa Thailand tingkat dasar. Subjek yang terlibat dalam uji coba adalah 12 mahasiswa Thailand yang kuliah di Universitas Negeri Yogyakarta (UNY). Uji coba tes berjumlah tiga orang, sedangkan uji coba kelayakan web berjumlah sembilan orang. Data yang digali dalam penelitian ini adalah data dari angket dan data uji coba tes. Data dari angket menggunakan teknik analisis deskriptif kuantitatif dan data uji coba tes analisis menggunakan program ITEMAN. Hasil penelitian ini adalah sebagai berikut: (1) Proses pengembangan UKBIPUTH berbasis web terdiri atas dua tahap, yaitu tahap pengembangan tes dan pengembangan web. Tahap pengembangan tes diawali dengan penyusunan kisikisi, menyusun butir-butir soal dan ditelaah butir tes oleh ahli serta merevisi, uji coba tes, dan analisis butir tes. Selanjutnya tahap pengembangan web diawali dengan mendesain flowchart dan storyboard serta pembuatan produk, kemudian produk divalidasi oleh ahli media, uji coba skala kecil, dan uji coba skala besar; (2) Karakteristik tes pilihan ganda, tes benar/salah, dan tes menjodohkan memiliki validitas isi tes baik dan koefisien reliabilitas tes masing-masing kategori tinggi. Analisis butir tes berdasarkan tingkat kesukaran butir tes baik dan efektivitas pengecoh butir tes baik; (3) Hasil penilaian dari aspek tampilan web dengan berkategori baik; (4) Hasil penilaian dari aspek sistem web dengan berkategori baik.
\end{abstract}

Kata Kunci: tes berbasis web, tes Bahasa Indonesia bagi penutur Thailand

\section{Developing web-based Indonesian language reading test for Thai students at the Universitas Negeri Yogyakarta}

\begin{abstract}
This study aims to develop an elementary level web-based Indonesian reading comprehension test for Thai students. The data collection instruments included evaluation sheets for the material and media experts and questionnaires to individual students on the field trials. The test items were analysed using the Iteman. The quantitative descriptive analysis technique was used to analyse the data. The results of this study are as follows: (1) The process of developing the web-based UKBIPUTH is done in two steps; they are the development of test and the development of web. The development of test was started by developing test items and later validated by the experts, test try-out, and finally test items analysis; (2) Characteristics of the multiple-choice test, true-false test, and matching test are described as follows: the content validation was good and the test reliability of Alpha respectively 0.748, 0.762, and 0.772. Based on the analysis by using ITEMAN item, the tests have a good difficulty index and the effectiveness of the test items distractors are good because the distractors work well; (3) The final product gets the evaluation in the aspect of appearance which is categorized 'good' with an average score of 3.80; (4) The final product gets the evaluation in the system aspects is categorized as 'good' with an average score of 4.10. The web-based test tool, UKBIPUTH is fit to be used to measure elementary level Indonesian reading comprehension of Thai students.
\end{abstract}

Keywords: web-based test, Indonesian reading test for Thai students

How to Cite: Masae, A. (2019). Pengembangan tes membaca bahasa Indonesia berbasis web bagi mahasiswa Thailand di Universitas Negeri Yogyakarta. LingTera, 6(1), 91-99. doi:https://doi.org/10.21831/lt.v6i1.17088

This is an open access article under the $\underline{\mathrm{CC}-\mathrm{BY}-\mathrm{SA}}$ license. 


\section{LingTera,6 (1), 2019 - 91 \\ Aleeyah Masae}

\section{PENDAHULUAN}

Dewasa ini, perkembangan Bahasa Indonesia bagi penutur asing (BIPA), semakin hari semakin diminati oleh penutur asing (Arumdyahsari, Hs, \& Susanto, 2016; Ningrum, Waluyo, \& Winarni, 2017). Banyak lembagalembaga penyelenggaraan BIPA di Indonesia maupun di luar negeri. Di Indonesia, 36 perguruan tinggi, baik negeri maupun swasta menyelenggarakan program Darmasiswa dan 12 perguruan tinggi menyelenggarakan program Kemitraan Negara Berkembang (KNB) yang diselenggarakan oleh Kementerian Pendidikan dan Kebudayaan Republik Indonesia.

Mahasiswa asing yang belajar di Universitas Negeri Yogyakarta (UNY) berasal dari berbagai negara, namun yang terbanyak salah satu diantaranya adalah mahasiswa dari Thailand yang menuntut ilmu pada jenjang S-1, S-2, dan kursus bahasa dan budaya Indonesia. Minat mahasiswa Thailand yang menempuh kuliah di sini tidak hanya dari beasiswa tersebut, selain itu mahasiswa yang belajar dengan biaya mandiri mulai muncul karena UNY merupakan perguruan tinggi yang terkenal pada bidang pendidikannya, sehingga menjadi daya tarik tersendiri bagi orang Thailand. Saat ini, ada beberapa Perguruan Tinggi di Thailand yang mahasiswanya datang ke UNY untuk pertukaran pelajar dan menjalin kemitraan Memorandum of Understanding (MOU), yakni University Naresuan, Universitas Rachapat Yala, dan University Siangmai (Kantor Urusan Internasional dan Kemitraandan Universitas Negeri Yogyakarta, 2014).

Di Thailand bahasa Indonesia adalah salah satu bahasa asing yang digemari dan popular dewasa ini (Adiutama, 2017). Kebutuhan akan bahasa Indonesia semakin meningkat (Astika, 1995). Hal tersebut dikukuhkan dengan mengadakan Association of Southeast Asian Nation (ASEAN) pada tahun 2015 mendatang yang membuat daya tarik penutur Thai belajar bahasa Indonesia. Ada kemungkinan besar Bahasa Indonesia memiliki peluang menjadi bahasa pengantar dalam berbagai keperluan, seperti perniagaan dan penyampaian informasi selain Bahasa Inggris.

Bahasa Indonesia dapat menjadi bahasa yang berpengaruh dan akan banyak dipelajari oleh penutur asing sekiranya secara ekonomisosial-politik negara Indonesia memiliki peran yang besar (Nurhadi, 2006). Adanya perkembangan ekonomi, sosial dan politik di masyarakat ASEAN yang pesat menuntut seseorang untuk mempunyai kemampuan berbahasa Indonesia dengan baik dan benar. Seseorang yang ingin menyerap berbagai informasi dan memperoleh kemajuan paling tidak harus memiliki empat keterampilan berbahasa Indonesia, yaitu menyimak, berbicara, membaca dan menulis.

Dalam menunjang keberhasilan belajar terutama yang perlu dikuasai ialah keterampilan membaca (Ahuja \& Ahuja, 2010; Alderson, 2000), yakni mulai membaca mengenal huruf dan selanjutnya memahami apa yang dibaca. Keterampilan membaca memiliki peran sangat penting (Halimah, 2014; Rumidjan, Sumanto, \& Badawi, 2017). Grabe (2009) menyatakan bahwa keterampilan membaca pentingnya untuk mengenali bahwa banyak orang di seluruh dunia yang belajar membaca lebih dari satu bahasa untuk berbagai alasan, termasuk dalam interaksi dengan negara multibahasa, gerakan imegrasi, transporttasi global, peluang pendidikan lanjutan, dan penyebaran bahasa sebagai alasan berkomunikasi yang lebih luas. Banyak manfaat yang diperoleh dari kegiatan membaca dan menggunakan keterampilan dasar membaca dalam pekerjaan dan kehidupan sehari-hari.

Membaca merupakan kebutuhan dasar setiap orang sebagai bekal untuk memperoleh ilmu pengetahuan (Prayitno, 2010). Grabe (2009) juga menyatakan bahwa banyak mahasiswa yang menggunakan keterampilam membaca bahasa kedua atau bahasa asing untuk terlibat dalam studi lebih lanjut, mendapatkan pekerjaan yang lebih baik, wisata, mendapatkan informasi baru, berkomunikasi dengan orang lain dan sebagainya. Begitu juga dengan mahasiswa Thailand yang belajar keterampilam membaca bahasa Indonesia.

Membaca bagaikan jendela dunia (Ismail, 2016; Nugrahanto, 2014; Permatasari, 2015). Seperti halnya dengan BIPA yang merupakan jendela bagi para warga asing. Dengan membaca, pembelajar akan memperoleh berbagai informasi. Semakin banyak membaca semakin banyak pula informasi yang diperoleh. Sekarang sangat mudah untuk memperoleh informasi lewat internet seperti berita, ilmu pengetahuan, teknologi, dan lain-lain. Dengan demikian, kegiatan membaca berbagai informasi tersebut akan menambah wawasan dan memperluas dunia seseorang.

Keterampilan membaca ini memerlukan latihan yang berkesinambungan untuk melatih kebiasaan membaca agar kemampuan membaca pemahaman dapat dicapai. Kegiatan pembelajaran membaca juga memerlukan evaluasi untuk mengetahui ketercapaian. Penguasaan terhadap 


\section{LingTera, 6 (1), 2019 - 92 \\ Aleeyah Masae}

pemahaman membaca tersebut dapat diketahui melalui rangkaian kegiatan pengukuran. Dalam pelaksanaan belajar mengajar di kelas salah satu alat yang dipakai oleh pengajar untuk mengukur tentang keberhasilan atau ketercapaian peserta didik dalam memahami suatu materi yang telah diberikan adalah dengan melakukan tes.

Model tes dalam pembalajaran bahasa saat ini umumnya masih bersifat tradisional. Pengajar dan peserta didik bertemu di suatu ruangan yang disepakati, untuk melaksanakan ujian. Model tes seperti ini baik saja, karena dosen bisa langsung mengawasi, sehingga pelaksanaan tes tersebut dapat terjaga. Namun, bila dikaji lebih mendalam, model tes seperti ini, relatif tidak efektif dan efisien. Dari segi biaya, tes tersebut membutuhkan biaya yang tidak sedikit, apalagi bila jumlah soal dan jumlah pesertanya banyak dan dari sisi waktu, penguji dan examiner sangat terpancang dengan waktu yang telah ditentukan, sehingga bila salah satu pihak tidak bisa hadir pada waktu yang telah ditentukan, maka harus ada kesepakatan baru lagi.

Kemajuan teknologi informasi telah berkembang sangat pesat dan dimungkinkan pelaksanaan eksplorasi dalam pengembangan pendidikan. Teknologi informasi kini menjadi bagian tak terpisahkan dengan dunia pendidikan. Kemajuan teknologi informasi telah mengubah praktik dunia pendidikan menuju ke arah yang tidak berbatas ruang dan waktu. Sumber-sumber belajar dan berbagai tes tidak hanya yang secara fisik nyata di dekat kita, hal tersebut bisa kita dapatkan lewat internet. Selain itu, pencarian materi otentik lebih dimungkinkan melalui internet karena informasi yang diperoleh dari internet lebih baru.

Penggunaan teknologi merupakan salah satu solusi untuk mengatasi permasalahan tersebut. Teknologi seperti komputer sebenarnya telah lama digunakan untuk pengukuran, yaitu tes Computer-Based TOEFL dan Internet-Based TOEFL. Adanya tes berbasis web memudahkan mahasiswa untuk mengetahui kemahiran bahasa Inggis mereka dengan tingkatan respon dan menyelesaikan tes yang lebih cepat dibandingkan dengan tes yang menggunakan kertas dan pensil (paper-and-pencil tests). Penelitian (Bodmann \& Robinson, 2004) yang meneliti tentang perbedaan tes online dengan tes yang meng-gunakan kertas dan penil. Hasil menunjukkan bahwa mahasiswa menyelesaikan penilaian berbasis komputer lebih cepat dari penilaian berbasis kertas, dengan tidak ada perbedaan dalam skor.
Pengembangan aplikasi ujian BIPA secara online atau berbasis web masih minim pengembangannya. Padahal apabila pengembangan sistem ujian berbasis web ini dikembangkan, banyak keuntungan yang diperoleh. Dipandang dari segi tempat dan waktu ujian menjadi lebih fleksibel karena bisa dilakukan di mana dan kapan saja. Dari segi biaya, akan banyak menghemat biaya karena sudah tidak dibutuhkan lagi kebutuhan akan kertas dan penggandaan soal. Dari segi hasil tes dapat dilihat secara langsung yang sejatinya sangat berguna untuk tujuan pendidikan.

Dewasa ini, tes Bahasa Indonesia yang terstandar yang mampu mengukur tingkat kemahiran berbahasa Indonesia, yaitu Uji Kemahiran Berbahasa Indonesia (UKBI). UKBI bertujuan untuk memberikan penilaian standar kemampuan seseorang (pengguna bahasa Indonesia) dalam berbahasa Indonesia tanpa mempertimbangkan kapan, di mana, dan bagaimana kemampuan itu diperoleh (Iskandarwassid \& Sunendar, 2008, p. 272) (Maryanto, 2001;). Namun, tes tersebut lebih mengukur kemahiran berbahasa penutur asli bahasa Indonesia, belum mengukur tingkat penutur asing dengan baik karena soal-soal terlalu sukar bagi penutur asing.

Selain tes UKBI, ada juga tes kemahiran berbahasa Indonesia penutur asing yaitu tes Uji Kemahiran Berbahasa Indonesia bagi Penutur Asing (UKBIPA) sesi membaca dikembangkan oleh (Annisa, 2013). Namun, tes ini hanya memiliki tes pilihan ganda, perlu mengadakan jenis tes bervariasi, contohnya tes benar salah (TrueFalse Test) dan tes menjodohkan (Matching Test) dan sebagainya. Oleh karena itu, perlu adanya upaya pengembangan sebuah tes bahasa yang mirip dengan UKBIPA berbasis web yang bisa diujikan pada mahasiswa Thailand, yaitu Uji Kemampuan Bahasa Indonesia bagi Penutur Thailand (UKBIPUTH) keterampilan membaca tingkat dasar.

\section{METODE}

Penelitian ini menggunakan metode penelitian pengembangan. Penelitian ini berusaha mengembangkan suatu produk yang berupa webbased tes keterampilan membaca Bahasa Indonesia untuk pembelajar Thailand. Langkah-langkah dalam proses ini memperlihatkan bentuk pengulangan untuk pengembangan suatu produk.

Prosedur penelitian ini diadaptasi dari model desain pengembangan (Gall, Gall, \& Borg, 2003). Gall et al. (2003) dan model pengembangan tes oleh McIntire (Ardiyanto \& Fajaruddin, 
2019; Ariyanto, 2017; Setiawan, Fajaruddin, \& Andini, 2019) yang menjadi delapan langkah seperti terpapar pada Gambar 1.

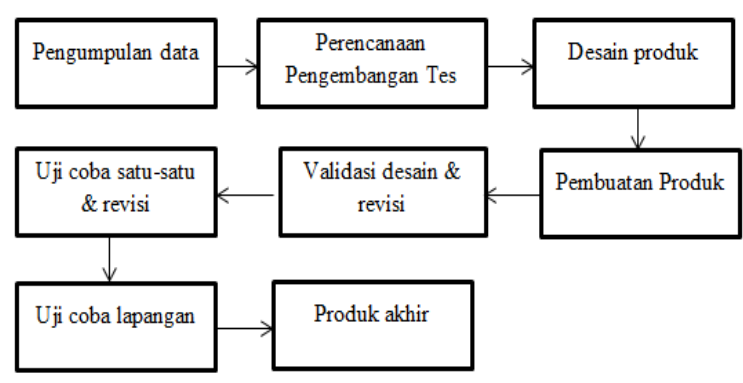

Gambar 1. Prosedur Pengembangan Desain Uji Coba Produk

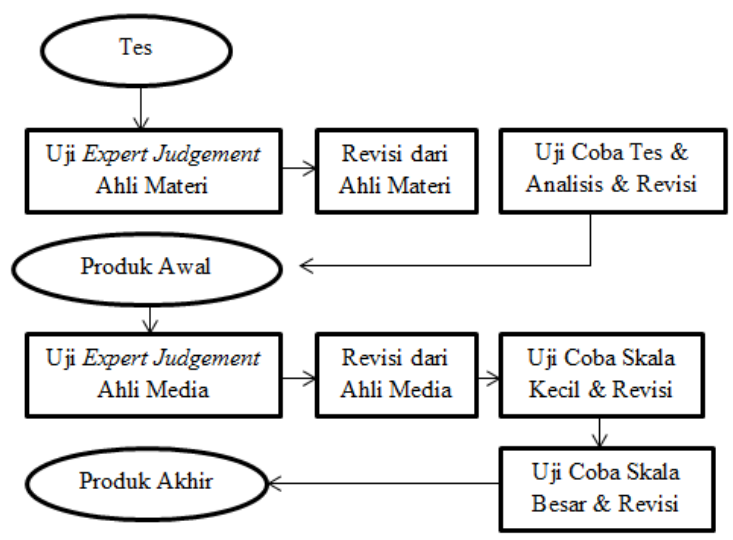

Gambar 2. Desain Uji Coba Produk

Desain uji coba ini dilakukan untuk mengantisipasi produk yang dikembangkan. Sebelum diujicobakan produk oleh pengguna diperlukan validasi, komentar, dan saran dari ahli materi dan ahli media supaya produk yang dikembangkan layak dan tidak mengalami kesalahan. Uji coba dilakukan melalui dua tahap, yaitu tahap uji coba tes dan uji coba kelayakan web. Uji coba web memiliki dua tahap, yaitu uji coba skala kecil dan uji coba skala besar.

Subjek uji coba pada penelitian ini adalah uji coba expert judgment, yaitu dua ahli materi dan satu ahli media dan dua belas mahasiswa Thailand yang kuliah di Universitas Negeri Yogyakarta. Untuk 3 orang mahasiswa uji coba soal (tryout). Sedangkan, uji coba kelayakan web berjumlah 9 orang, yang terdiri 2 orang uji coba skala kecil dan 7 uji coba skala besar.

Instrumen yang digunakan dalam penelitian ini adalah dokumen, kuesioner, dan tes membaca bahasa Indonesia. Dokumen yang dilakukan untuk mengkaji teori-teori yang berkaitan dengan tes membaca Bahasa Indonesia untuk penutur asing dan mengkaji teori-teori tentang web based test. Instrumen yang berupa kuesioner berisi tentang pertanyaan yang berkaitan dengan penilaian untuk tes membaca BIPUTH berbasis web untuk mengetahui kelayakan produk termasuk aspek materi (isi), aspek sistem, dan aspek tampilan.

Penelitian ini menggunakan tes objektif. Sistem untuk menghitung skor akhir tes membaca BIPUTH ini menggunakan sistem penskoran tanpa denda. Jadi, penskoran dalam tes ini setiap item diberi skor 1 (satu). Apabila item dijawab betul sesuai dengan kunci jawaban, maka diberikan skor 1 , dan yang dijawab salah, maka skornya 0.

Analisis data dilakukan melalui dua cara, yaitu analisis butir soal dan analisis data dari angket. Data kuantitatif yang diperoleh melalui analisis data hasil uji coba butir soal dilakukan dengan Iteman. Data kuantitatif yang diperoleh melalui angket dianalisis secara deskriptif kuantitatif kemudian akan dikonversikan ke data kualitatif dengan menggunakan skala 5 seperti pada Tabel 1 .

Table 1. Konversi Skor pada Skala 5

\begin{tabular}{ccc}
\hline Skor & Interval Skor & Kriteria \\
\hline 5 & $X>4,21$ & Sangat Baik (A) \\
4 & $3,40<X \leq 4,21$ & Baik (B) \\
3 & $2,60<X \leq 3,40$ & Cukup (C) \\
2 & $1,79<X \leq 2,60$ & Kurang (D) \\
1 & $X \leq 1,79$ & Sangat Kurang (E) \\
\hline
\end{tabular}

(Sukardjo, 2006)

Dalam penelitian ini, ditetapkan nilai kelayakan produk minimal "B", dengan kategori "baik", sebagai hasil penilaian baik dari ahli media, ahli materi maupun mahasiswa. Jika hasil penilaian akhir keseluruhan aspek dengan nilai minimal "B" (baik), maka produk hasil pengembangan tersebut sudah dianggap layak digunakan sebagai media atau sumber belajar.

\section{HASIL DAN PEMBAHASAN}

\section{Kebutuhan Alat Tes Berbasis Web}

Dengan perkembangan teknologi yang sangat pesat diperlukan sebuah alat tes UKBIPUTH berbasis web seperti tes UKBIPA untuk mengukur pemahaman membaca mahasiswa Thailand di UNY. Oleh kerena itu, pengembangan alat tes UKBIPUTH berbasis web perlu dilakukan, sehingga pengunaannya tidak terbatas ruang dan waktu.

Hasil analisis kebutuhan pengembangan alat tes UKBIPUTH berbasis web diperoleh dari analisis kebutuhan mahasiswa Thailand di UNY. Berdasarkan hasil analisis dapat dideskripsikan bahwa $100 \%$ mahasiswa yang senang dan lebih 


\section{LingTera,6 (1), 2019 - 94 \\ Aleeyah Masae}

tertarik dengan pengujian berbasis web. $100 \%$ mahasiswa yang tertarik dan setuju untuk mengadakan pengujian bahasa Indonesia online. Maka dari itu, alat tes membaca Bahasa Indonesia berbasis web yang akan dihasilkan dapat membantu mahasiswa dalam melaksanakan tes bahasa Indonesia.

\section{Hasil Desain}

Pertama, pengembangan tes diawali dengan penyusunan kisi-kisi, menyusun butir-butir soal dan ditelaah butir tes oleh ahli serta merevisi, uji coba tes, dan analisis butir tes. Soal ini memiliki enam puluh satu butir soal yang didesain. Setelah divalidasi oleh ahli materi dan memperbaikan soal, kemudian peneliti hanya memilih empat puluh lima butir soal yang diujicobakan oleh 3 mahasiswa Thailand. Kedua, pembuatan Flowchart dan Story Board. Langkah ini dilakukan penyusunan konsep diikuti dengan penyusunan flowchart dan storyboard. Flowchart dan storyboard disusun untuk mempermudah pengembangan program yang akan dipergunakan dalam pengembangan Alat Tes UKBIPUTH berbasis web keterampilan membaca.

\section{Hasil Pengembangan}

Produk awal alat tes yang dikembangkan diberi identitas UKBIPUTH (Uji Kemampuan Bahasa Indonesia bagi Penutur Thailand) dengan alamat domain: http://ukbiputh.com. Pada alat tes UKBIPUTH ini memiliki dua bagian, yaitu bagian perserta tes dan bagian admin. Desain tampilan berisi desain halaman-halaman yang akan ditampilkan sesuai dengan fasilitas menu program yang dipilih.

Tampilan perserta tes adalah tampilan untuk perserta tes atau mahasiswa dalam melaksanakan tes. Pada halaman ini memiliki lima halaman, yaitu halaman login, halaman selamat datang, halaman petunjuk umum, halaman ujian, dan halaman hasil ujian. Sedangkan, halaman admin memiliki delapan halaman, yaitu halaman login, halaman pengaturan ujian, halaman tambah data mahasiswa, halaman data soal, halaman tambah data soal, halaman hasil ujian, halaman peserta lulus ujian, laporan hasil ujian seluruh peserta.

\section{Hasil Uji Coba Produk}

Dalam uji coba alat tes pemahaman membaca bahasa Indonesia berbasis web diperoleh tiga jenis data, yaitu data validasi ahli materi, data validasi ahli media, dan data uji coba mahasiswa yang meliputi uji coba soal dan uji coba kelayakan web. Uji coba kelayakan web terdiri atas uji coba skala kecil dan uji coba skala besar.

Pertama, divalidasi oleh ahli materi yang dinilai dari aspek materi (isi), aspek konstruksi, dan aspek bahasa. Berdasarkan hasil validasi UKBIPUTH berbasis web dapat diketahui bahwa rerata responden yang paling rendah dari sembilan belas butir instrumen penilaian adalah rerata 3.00 dengan penilaian "baik" dan yang paling tinggi sebesar 4.44 dengan penilaian "sangat baik". Sementara itu, rerata penilaian yang paling rendah dari dua orang ahli sebesar rerata 3.68 dengan penilaian "sangat baik" dan yang paling tinggi sebesar rerata 4.47 dengan penilaian "baik". Dengan demikian secara umum, ahli yang menjadi renponden dalam validasi materi memberi penilaian tes UKBIPUTH yang dikembangkan adalah "baik" dengan rerata penilaian 3.84. Informasi tentang hasil uji coba produk dapat dilihat pada Tabel 2.

Tabel 2. Hasil Validasi Ahli Materi

\begin{tabular}{clcc}
\hline No. & \multicolumn{1}{c}{ Kriteria } & Frekuensi & Persentase \\
\hline 1. & Sangat Baik & 5 & 13 \\
2. & Baik & 22 & 58 \\
3. & Cukup & 11 & 29 \\
4. & Kurang & - & - \\
5. & Sangat Kurang & - & - \\
& Jumlah & 38 & $100 \%$ \\
\hline
\end{tabular}

Tabel 2 menunjukan bahwa dari 19 jumlah indikator kualitas materi, 5 butir (13\%) dinilai dengan kriteria sangat baik, 22 butir (58\%) dinilai dengan kriteria "baik", dan 11 butir (29\%) dinilai dengan kriteria "cukup".

Kedua, hasil analisis butir soal. Data uji coba menunjukan bahwa masih ada soal yang membingungkan mahasiswa, khususnya soal yang berkaitan dengan tabel jadwal kereta. Sebagian siswa merasa, kebingungan dalam petunjuk soal, khususnya petunjuk soal menjodohkan. Kesulitan yang lain adalah tentang kata singkatan yang terdapat dalam materi. Mereka tidak kesulitan dalam keseluruhan materi bacaan, karena kosa-kata sudah tidak asing bagi mereka.

Tingkat kesukaran, daya pembeda, dan pengecoh dengan menggunakan program ITEMAN. Kriteria ideal butir soal yang baik memiliki tingkat kesulitan berdasarkan rentang 0,30 sampai 0,70 , memiliki daya pembeda pada rentang 0,30 sampai 0,40 atau lebih, dan memiliki setiap pengecoh berfungsi.

Butir soal yang diterima atau yang baik dan diaktifkan sebanyak 38 butir soal. Butir soal yang ditolak sebanyak 7 butir soal. Sementara itu, 


\section{LingTera, 6 (1), 2019 - 95 \\ Aleeyah Masae}

soal-soal yang belum diujicobakan sebanyak 15 butir soal juga ditahankan sebagai koleksi soal. Akan tetapi, soal-soal tersebut dinonaktifkan, sehingga soal-soal ini belum dapat diakses oleh penguna atau peserta tes. Dengan demikian, terdapat 53 butir soal dalam database UKBIPUTH berbasis web yang terdiri dari 38 butir soal dalam status aktif.

Berdasarkan hasil analisis butir soal dengan menggunakan Iteman, soal tes pilihan ganda memiliki koefisien reliabilitas Alpha sebesar 0,748 , soal tes benar/salah memiliki koefisien reliabilitas Alpha sebesar 0,762, dan soal tes menjodohkan memiliki koefisien reliabilitas Alpha sebesar 0,772. Besarnya indek ini menggambarkan tingkat mutu tes. Semakin besar indeks keandalan, semakin tinggi mutu tes karena kesalahan kecil. Berdasarkan hasil analisis dengan mengacu koefisien reliabilitas, yaitu interpretasi korelasi tinggi maka dapat dikatakan tes ini handal.

Ketiga, hasil analisis validasi ahli media yang meliputi aspek tanpilan dan aspek sistem. Berdasarkan validasi dari ahli media pada aspek tampilan dapat diketahui bahwa kualitas alat tes UKBIPUTH berbasis web yang dikembangkan adalah "baik" dengan rerata penilaian 3.64. Informasi tentang penilaian ahli media dapat dilihat pada Tabel 3.

Tabel 3. Validasi Ahli Media Aspek Tampilan

\begin{tabular}{clcc}
\hline No. & \multicolumn{1}{c}{ Kriteria } & Frekuensi & prosentase \\
\hline 1. & Sangat Baik & 1 & 7 \\
2. & Baik & 7 & 50 \\
3. & Cukup & 6 & 43 \\
4. & Kurang & - & - \\
5. & Sangat Kurang & - & \\
& Jumlah & 14 & $100 \%$ \\
\hline
\end{tabular}

Tabel 3 menunjukan bahwa dari 14 jumlah indikator kualitas tampilan, 1 butir (7\%) dinilai dengan kriteria "sangat baik", 7 butir $(50 \%)$ dinilai dengan kriteria "baik", dan 6 butir (43\%) dinilai dengan kriteria "cukup".

Validasi dari ahli media berdasarkan aspek sistem dapat diketahui bahwa kualitas Alat Tes UKBIPUTH berbasis web yang dikembangkan adalah "baik" dengan rerata 4,20. Informasi tentang penilaian ahli media dari aspek sistem dapat dilihat pada Tabel 4.

Keempat, hasil analisis uji coba skala kecil. Berdasarkan hasil uji coba skala kecil dapat diketahui bahwa rerata responden yang paling rendah dari empat belas butir instrument penilaian adalah 2,00 dan yang paling tinggi sebesar 4,50 . Sementara itu, rerata penilaian yang paling rendah dari dua orang responden sebesar 3,00 dan yang paling tinggi sebesar 4,50. Dengan demikian secara umum, mahasiswa yang menjadi responden dalam uji coba skala kecil aspek tampilan memberi penilaian adalah "baik" dengan rerata penilaian 3,89. Informasi tentang hasil uji coba produk dapat dilihat pada Tabel 5:

Tabel 4. Validasi Ahli Media Aspek Sistem

\begin{tabular}{clcc}
\hline No. & \multicolumn{1}{c}{ Kriteria } & Frekuensi & Persentase \\
\hline 1 & Sangat Baik & 2 & 20 \\
2 & Baik & 8 & 80 \\
3 & Cukup & - & - \\
4 & Kurang & - & - \\
5 & Sangat Kurang & - & \\
& Jumlah & 10 & $100 \%$ \\
\hline
\end{tabular}

Tabel 5. Hasil Uji Coba Skala Kecil Aspek tampilan

\begin{tabular}{clcc}
\hline No. & \multicolumn{1}{c}{ Kriteria } & Frekuensi & Persentase \\
\hline 1. & Sangat Baik & 6 & 21 \\
2. & Baik & 16 & 57 \\
3. & Cukup & 3 & 11 \\
4. & Kurang & 3 & 11 \\
5. & Sangat Kurang & - & \\
& Jumlah & 28 & $100 \%$ \\
\hline
\end{tabular}

Tabel 5 menunjukan bahwa dari 28 jumlah indikator kualitas tampilan, $21 \%$ dinilai dengan kriteria "sangat baik", 57\% dinilai dengan kriteria "baik", 11\% dinilai dengan kriteria "cukup", dan 11\% dinilai dengan kriteria "kurang".

Berdasarkan hasil uji coba skala kecil dari aspek sistem dapat diketahui bahwa rerata responden yang paling rendah dari sepuluh butir instrumen penilaian adalah 3,00 dan yang paling tinggi sebesar 4,50. Sementara itu, rerata penilaian dua orang responden sebesar 4,10. Dengan demikian secara umum, mahasiswa yang menjadi renponden dalam uji coba skala kecil memberi penilaian adalah "baik" dengan rerata penilaian 4,10. Informasi tentang hasil uji coba produk dapat dilihat pada Tabel 6 .

Tabel 6. Hasil Uji Coba Skala Kecil Aspek Sistem

\begin{tabular}{clcc}
\hline No. & \multicolumn{1}{c}{ Kriteria } & Frekuensi & Persentase \\
\hline 1 & Sangat Baik & 5 & 25 \\
2 & Baik & 12 & 60 \\
3 & Cukup & 3 & 15 \\
4 & Kurang & - & - \\
5 & Sangat Kurang & - & - \\
& Jumlah & 20 & $100 \%$ \\
\hline
\end{tabular}

Tabel 6 menunjukan bahwa dari 20 jumlah indikator kualitas aspek sistem, $25 \%$ dinilai dengan kriteria "sangat baik", $60 \%$ dinilai dengan 


\section{LingTera,6 (1), 2019 - 96 \\ Aleeyah Masae}

kriteria "baik", dan 15\% dinilai dengan kriteria "cukup".

Kelima, hasil analisis uji coba skala besar. Berdasarkan hasil uji coba skala besar dari aspek tampilan dapat diketahui bahwa rerata responden yang paling rendah dari empat belas butir instrument penilaian adalah 3,42 berkategori "baik" dan yang paling tinggi sebesar 4,42 berkategori "sangat baik". Sementara itu, rerata penilaian yang paling rendah dari tujuh orang responden sebesar 2,71 berkategori "cukup" dan yang paling tinggi sebesar 4,14 berkategori "baik". Dengan demikian, secara umum mahasiswa yang menjadi renponden dalam uji coba lapangan aspek tampilan memberi penilaian alat tes UKBIPUTH berbasis web yang dikembangkan adalah "baik" dengan rerata penilaian 3,80. Informasi tentang hasil uji coba produk dapat dilihat pada Tabel 7.

Tabel 7. Hasil Uji Coba Aspek Tampilan

\begin{tabular}{clcc}
\hline No. & \multicolumn{1}{c}{ Kriteria } & Frekuensi & Persentase \\
\hline 1. & Sangat Baik & 18 & 18 \\
2. & Baik & 51 & 52 \\
3. & Cukup & 23 & 24 \\
4. & Kurang & 6 & 6 \\
5. & Sangat Kurang & - & \\
& Jumlah & 98 & $100 \%$ \\
\hline
\end{tabular}

Tabel 7 menunjukkan bahwa dari 376 jumlah indikator kualitas tampilan, 98 butir (18\%) dinilai dengan kriteria "sangat baik", 52\% dinilai dengan kriteria "baik", 24\% dinilai dengan kriteria "cukup", dan $6 \%$ dinilai dengan kriteria "kurang".

Tabel 8. Hasil Uji Coba Lapangan Aspek Sistem

\begin{tabular}{clcc}
\hline No. & \multicolumn{1}{c}{ Kriteria } & Frekuensi & prosentase \\
\hline 1. & Sangat Baik & 18 & 26 \\
2. & Baik & 39 & 56 \\
3. & Cukup & 13 & 18 \\
4. & Kurang & - & - \\
5. & Sangat Kurang & - & \\
& Jumlah & 70 & $100 \%$ \\
\hline
\end{tabular}

Berdasarkan hasil uji coba skala besar dari aspek sistem dapat diketahui bahwa rerata responden yang paling rendah dari sepuluh butir instrument penilaian adalah 3,57 dan yang paling tinggi sebesar 4,42. Sementara itu, rerata penilaian yang paling rendah dari tujuh orang responden sebesar 3,40 dan yang paling tinggi sebesar 4,60. Dengan demikian secara umum, mahasiswa yang menjadi renponden dalam uji coba lapangan memberi penilaian Alat Tes UKBIPUTH berbasis web yang dikembangkan adalah "baik" dengan rerata penilaian 4,10. Informasi tentang hasil uji coba produk dapat dilihat pada Tabel 8 . Tabel 8 menunjukan bahwa dari 70 jumlah indikator kualitas tampilan, 26\% dinilai dengan kriteria "sangat baik", $56 \%$ dinilai dengan kriteria "baik", dan $18 \%$ dinilai dengan kriteria"cukup".

\section{Kajian Produk Akhir}

Alat tes UKBIPUTH berbasis web ini menggunakan hosting www.ukbiputh.com. Web yang dikembangkan ini dapat diakses mahasiswa melalui internet di mana saja dan kapan saja.

Produk akhir yang dikembangkan dalam penelitian ini telah mengalami perbaikan sesuai dengan saran-saran yang dikemukakan oleh ahli media, ahli materi, uji coba soal, uji coba skala kecil, dan uji coba skala besar. Produk ini diharapkan menjadi media pendukung penyelenggaraan sistem pengujian di BIPA UNY maupun di Thailand yang menyelenggarakan matakuliah bahasa Indonesia. Selain itu diharapkan menjadi sistem pengadministrasian lebih aman, fleksibel, memberikan kemudahan dalam pemakaian.

Keamanan produk yang dikembangkan ini dengan menerapkan dua pintu masuk untuk peserta tes dan admin atau guru. Setiap pengguna didaftar oleh admin, sehingga pengguna atau peserta tes yang belum terdaftar sebagai user tidak bisa melakukan akses ke dalam UKBIPUTH berbasis web. Apabila, pengguna ingin melakukan tes, harus hubungi admin dahulu semoga mendapakan username dan password dari admin.

Sebagai produk hasil pengembangan alat tes UKBIPUTH berbasis web ini memiliki kelemahan dan kelebihan. Kelebihannya adalah pertama, UKBIPUTH berbasis web ini dapat di teskan oleh mahasiswa di mana saja dan kapan saja, Oleh karena itu, dosen tidak perlu lagi datang ke dalam kelas. Dosen cukup memberikan alamat web kepada mahasiswa untuk mengakses soal-soal ujian yang akan diteskan

Kedua, setiap butir soal dibatasi oleh waktu, yaitu setiap soal memiliki waktu 70 detik yang terdiri 38 butir soal. Jadi, waktu keseluruhan adalah 45 menit. Hal ini memungkinkan mahasiswa untuk tidak saling bertukar jawaban, membuka buku atau pun membuka kamus. Mahasiswa akan lebih fokus kepada soal dan memikirkan jawaban karena jika mereka lalai mereka akan kehilangan kesempatan untuk menjawab soal dengan benar. Di samping itu, karena dibatasi oleh waktu, fleksibilitas mahasiswa dalam belajar pun akan meningkat. Mahasiswa akan mempelajari materi ujian secara rinci dan mendalam. 


\section{LingTera,6 (1), 2019 - 97 \\ Aleeyah Masae}

Kecenderungan mahasiswa yang bergantung kepada mahasiswa lain yang lebih pintar akan hilang. Mereka akan lebih fokus mengasah kemampuan mereka sendiri dengan meningkatkan daya belajar secara mandiri. Dengan demikian, mahasiswa akan terbiasa belajar dengan intensitas yang tinggi, yang pada akhirnya akan berimbas pada prestasi belajar mereka.

Ketiga, dosen tidak perlu lagi mengolah nilai atau skor karena sudah sistemlah yang secara otomatis mengolah nilai. Jika peserta telah selesai mengerjakan ujian, jawaban peserta diproses untuk menghasilkan informasi nilai yang diperoleh. Kemungkinan dosen bersikap subjektif dalam memberikan nilai pun dapat diminimalisir. Selain itu, tes ini juga memberikan feedback yang cepat. Artinya, mahasiswa akan mengetahui nilai atau skor secara langsung. Begitu mereka selesai ujian nilai atau skor akan ditampilkan.

Keempat, UKBIPUTH berbasis web menggunakan sistem random, sehingga masingmasing peserta tes akan mendapat butir soal yang berbeda-beda, untuk meminimalkan kemungkinan terjadinya kecurangan. Jika, peserta tes sudah login dan mengerjakan beberapa soal, kemudian dimatikan atau log off program, dengan otomatis username tersebut akan diblog membuat mahasiswa tidak bisa mengakses pada halaman ujian. Jika mahasiswa akan mengakses, ia harus menghubungi admin agar diaktifkan passwordnya kembali. Setelah diaktifkan oleh admin dan apabila peserta tes melogin akan mendapatkan soal yang berbeda dengan yang sebelumnya.

Selain kelebihan-kelebihan tersebut, alat tes UKBIPUTH berbasis web ini juga memiliki beberapa kelemahan-kelemahan, diantaranya adalah pertama, alat tes UKBIPUTH berbasis web yang dikembangkan ini memiliki tiga bentuk tes, yaitu tes pilihan ganda, tes benar/salah, dan tes menjodohkan. Alat tes UKBIPUTH berbasis web ini menggunakan sistem random, sehingga ketiga bentuk tes tersebut tidak bisa dipisahkan dan harus menggunakan format jawaban yang sama, yaitu A, B, C, dan D. Untuk soal benar/ salah yang digunakan hanya format $\mathrm{A}$ (salah) dan B (benar) dan untuk format $\mathrm{C}$ dan $\mathrm{D}$ dikosongkan. Kedua, jika terjadi gangguan teknis seperti mati listrik, akses internet lambat, komputer mengalami kerusakan, maka akan menghambat pelaksanaan tes.

Keterbatasan Penelitian

Penelitian pengembangan alat tes UKBIPUTH berbasis web keterampilan membaca ini belum sempurna. Hal ini, berarti alat tes tersebut memiliki keterbatasan. Pertama, soal tes yang terbentuk dalam alat tes UKBIPUTH berbasis web ini kurang ideal, karena soal yang tersedia hanya satu paket. Oleh karena itu perlu ditambah paket soal yang lain, sehingga setiap peserta tes akan dapat butir soal yang berbeda-beda. Dari jumlah paket soal yang cukup banyak memungkinkan pemilihan soal secara random sehingga peserta tes akan mendapatkan soal yang berbeda. Hal ini dilakukan untuk menghindari adanya kerjasama antara peserta tes.

Kedua, Penelitian yang dilakukan masih terbatas pada mahasiswa Thailand di UNY hanya berjumlah 12 orang dan hanya satu keterampilan, yaitu keterampilan membaca. Untuk mengatakan produk tersebut layak perlu dilakukan penelitian lebih lanjut pada skala besar yaitu untuk mahasiswa asing di UNY dan keterampilan berbahasa yang lain selain membaca. Walaupun produk yang dihasilkan ini telah melalui proses pengembangan, namun masih dikatakan sederhana dan belum sempurna.

Ketiga, penelitian ini hanya terbatas pada tes hasil belajar, tidak berlaku pada tes seleksi dan tes penempatan. Keempat, penelitian ini menggunakan teori tes klasik, yaitu program ITEMAN. Jika dipergunakan untuk seluruh mahasiswa Thailand, mestinya pengukuran menggunakan teori tes modern.

\section{SIMPULAN}

Berdasarkan hasil pelaksanaan penelitian dan pengembangan alat tes UKBIPUTH berbasis web sesi pemahaman membaca, dapat ditarik sejumlah kesimpulan. Pertama, dua langkah besar yang dilakukan dalam penelitian ini, yaitu langkah pengembangan tes dan pengembangan $w e b$. Tahap pengembangan tes diawali dengan penyusunan kisi-kisi, menyusun butir-butir soal dan ditelaah butir tes oleh ahli serta merevisi, uji coba tes, dan analisis butir tes. Selanjutnya, tahap pengembangan web diawali dengan mendesain flowchart dan storyboard serta pembuatan produk, kemudian produk divalidasi oleh ahli media, uji coba skala kecil, dan uji coba skala besar.

Kedua, karakteristik tes tersebut adalah validitas isi tes baik. Tes pilihan ganda, tes benar/salah, dan tes menjodohkan memiliki koefisien reliabilitas tes masing-masing sebesar $0.748,0.762$, dan 0.772 dengan kategori tinggi. Hasil analisis uji coba butir tes berdasarkan tingkat kesukaran, daya beda dan efektivitas 


\section{LingTera, 6 (1), 2019 - 98 \\ Aleeyah Masae}

pengecoh menggunakan program Iteman. Pada analisis butir tes diperoleh: (1) tingkat kesukaran butir tes baik, (2) daya beda butir tes baik, dan (3) efektivitas pengecoh butir tes baik karena semua pengecoh berfungsi. Dari hasil analisis butir soal terdapat 38 buitr soal yang diterima dan 7 butir soal yang ditolak.

Ketiga, kelayakan web aspek tampilan dari hasil analisis uji coba mahasiswa Thailand dapat diketahui bahwa rerata responden yang paling rendah dari empat belas butir instrument penilaian adalah 3,42 berkategori "baik" dan yang paling tinggi sebesar 4,42 berkategori "sangat baik". Sementara itu, rerata penilaian yang paling rendah dari tujuh orang responden sebesar 2,71 berkategori "cukup" dan yang paling tinggi sebesar 4,14 berkategori "baik". Dengan demikian, secara umum mahasiswa yang menjadi renponden dalam uji coba lapangan aspek tampilan memberi penilaian alat tes UKBIPUTH berbasis web yang dikembangkan adalah "baik" dengan rerata penilaian 3,80.

Keempat, kelayakan web aspek sistem dari hasil analisis uji coba mahasiswa Thailand dapat diketahui bahwa rerata responden yang paling rendah dari sepuluh butir instrumen penilaian adalah 3,57 dan yang paling tinggi sebesar 4,42. Sementara itu, rerata penilaian yang paling rendah dari tujuh orang responden sebesar 3,40 dan yang paling tinggi sebesar 4,60. Dengan demikian secara umum, mahasiswa yang menjadi renponden dalam uji coba lapangan memberi penilaian alat tes UKBIPUTH berbasis web yang dikembangkan adalah "baik" dengan rerata penilaian 4,10 .

\section{DAFTAR PUSTAKA}

Adiutama, G. (2017). Tren anak muda Thailand belajar Bahasa Indonesia. Retrieved from https://www.kompasiana.com/genturtama/ 58e6650ae7afbd720ec119d9/tren-anakmuda-thailand-belajar-bahasaindonesia?page $=$ all

Ahuja, P., \& Ahuja, G. C. (2010). Membaca secara efektif dan efisien (T. Martian). Bandung: Kiblat Buku Utama.

Alderson, J. C. (2000). Assessing reading. Assessing Reading. https://doi.org/10.1017/cbo978051173293 5

Annisa, R. I. (2013). Pengembangan alat tes UKBIPA-membaca berbasis teknologi informasi untuk mengukur kompetensi membaca pembelajar BIPA. Universitas
Pendidikan Indonesia, Bandung.

Ardiyanto, H., \& Fajaruddin, S. (2019). Tinjauan atas artikel penelitian dan pengembangan pendidikan di Jurnal Keolahragaan. Jurnal Keolahragaan, 7(1), 83-93. https://doi.org/10.21831/JK.V7I1.26394

Ariyanto, A. (2017). Pengembangan tes Strukturen und Wortschatz berbasis web mengacu pada Gemeinsamer Europäischer Referenzrahmen (GER). LingTera, 4(1), 35-44.

https://doi.org/10.21831/lt.v4i1.13584

Arumdyahsari, S., Hs, W., \& Susanto, G. (2016). Pengembangan bahan ajar Bahasa Indonesia bagi Penutur Asing (BIPA) tingkat madya. Jurnal Pendidikan: Teori, Penelitian, Dan Pengembangan, 1(5), 828-834.

https://doi.org/http://dx.doi.org/10.17977/j p.v1i5.6263

Astika, G. (1995). Penelitian Bahasa Indonesia sebagai bahasa asing: Latar belakang, landasan teoritis dan prosedur pengumpulan data. Majalah Komunikasi Maranatha, 2(2).

Bodmann, S. M., \& Robinson, D. H. (2004). Speed and performance differences among computer-based and paper-pencil tests. Journal of Educational Computing Research, 31(1), 51-60. https://doi.org/10.2190/GRQQ-YT0F7LKB-F033

Gall, M. D., Gall, J. P., \& Borg, W. R. (2003). Educational research: an introduction (7th ed.). Boston, MA: Allyn and Bacon.

Grabe, W. (2009). Reading in a second language: Moving from theory to practice. Ernst Klett Sprachen.

Halimah, A. (2014). Metode cooperative integrated reading and composition (CIRC) dalam pembelajaran membaca dan menulis di SD/MI. AULADUNA: Jurnal Pendidikan Dasar Islam, 1(1), 27-35. Retrieved from http://journal.uinalauddin.ac.id/index.php/auladuna/article/ view/539

Iskandarwassid \& Sunendar, D. (2008). Strategi pembelajaran bahasa. Bandung: PT Remaja Rosdakarya.

Ismail, I. (2016). Korelasi antara kebiasaan membaca dengan kemampuan membaca pemahaman siswa kelas VIII SMP Negeri 
1 Rambah. Edu Research, 5(1), 63-66. Retrieved from http://ejournal.upp.ac.id/index.php/EDU/article/v iew/885

Kantor Urusan Internasional dan Kemitraandan Universitas Negeri Yogyakarta. (2014). UNY-Thailand. Retrieved from http://kuik.uny.ac.id/uny-thailand

Ningrum, R. K., Waluyo, H. J., \& Winarni, R. (2017). BIPA (Bahasa Indonesia Penutur Asing) sebagai upaya internasionalisasi universitas di Indonesia. In Proceedings Education and Language International Conference (Vol. 1). Semarang: Universitas Islam Sultan Agung. Retrieved from

http://jurnal.unissula.ac.id/index.php/ELI C/article/view/1294

Nugrahanto, W. (2014). Mengembangkan minat baca di masyarakat Desa Pasanggrahan dan Desa Malongpong Kecamatan Maja Kabupaten Majalengka. Dharmakarya, 3(1).

Nurhadi, N. (2006). Bagaimana meningkatkan kemampuan Membaca? Bandung: Sinar Baru Algesindo.

Permatasari, A. (2015). Membangun kualitas bangsa dengan budaya literasi. Bengkulu: Unit Penerbitan FKIP Universitas Bengkulu.

Prayitno, G. B. (2010). Penerapan metode CIRC untuk meningkatkan pemahaman wacana fiksi dan wacana non fiksi di kelas X SMA Al Islam 3 Surakarta tahun pelajaran 2009/2010. Universitas Muhammadiyah Surakarta, Surakarta.

Rumidjan, R., Sumanto, S., \& Badawi, A. (2017). Pengembangan media kartu kata untuk melatih keterampilan membaca permulaan pada siswa kelas 1 SD. Sekolah Dasar: Kajian Teori Dan Praktik Pendidikan, 26(1), 62-68. https://doi.org/http://dx.doi.org/10.17977/ um009v26i12017p062

Setiawan, A., Fajaruddin, S., \& Andini, D. W. (2019). Development an honesty and discipline assessment instrument in the integrated thematic learning at elementary school. Jurnal Prima Edukasia, 7(1), 919. https://doi.org/10.21831/jpe.v7i1.23117

Sukardjo, S. (2006). Kumpulan materi evaluasi pembelajaran. Yogyakarta: Program Pascasarjana Universitas Negeri Yogyakarta. 